\title{
Associated Persons Subject Status Domain
}

National Cancer Institute

\section{Source}

National Cancer Institute. Associated Persons Subject Status Domain. NCI Thesaurus.

Code C147178.

A domain utilized for the submission of subject status records related to persons associated with the study subject. 